\title{
TMM JURNAL MAGISTER MANAJEMEN UNIVERSITAS MATARAM

KEPUASAN KELUARGA PASIEN SEBELUM DAN SESUDAH PERUBAHAN STATUS PENGELOLAAN DI POLI PSIKIATRI RUMAH SAKIT JIWA PROVINSI NUSA TENGGARA BARAT

\author{
ABDULLAH ${ }^{1}$ \\ BUDI SANTOSO2) \\ H. RUSDAN $\left.{ }^{3}\right)$
}

\begin{abstract}
Patient satisfaction in hospital services is an indicator for the service quality. Mental Hospital of Nusa Tenggara Barat (RSJ NTB) as the only one technical institute in West Nusa Tenggara, specifically cover of services and development of services in mental health field has responsibility to support the realization of vision and mission of local governments to carry out the basic tasks and function as well as possible, including the success of the implementation of the national health insurance. The purpose of this research is to compare and analyze patient satisfaction before and after the status of management application become PPK-BLU in psychiatry ward in Mental Hospital of West Nusa Tenggara. The analysis used in this reserach is comparative descriptive with cross sectional approach. The research conducted in treatment room of Psychiatry ward in Mental Hospital NTB. The total number of respondents was 158 respondent. Patient satisfaction level was calculated using Parasuraman model (Responsibility, Assurance, Tangible, Empathy, and Responsiveness)), whereas the hypotheses with different two mean test for observation satisfaction before and after the local public service. Recommendations of this research is as an input and evaluation of the quality of health service in Mutiara Sukma Mental Hospital West Nusa Tenggara province. Expected later there are beterment of comfortable and improving service quality of each units that the goals to patient satisfaction continuously.
\end{abstract}

Keyword: Patient satisfication, BLUD

\section{PENDAHULUAN}

\subsection{Latar belakang}

Pada era globalisasi ini persaingan sangatlah tajam baik itu di pasar domestik ataupun pasar internasional. Agar dapat berkembang atau paling tidak dapat bertahan perusahaan harus dapat menghasilkan barang atau jasa dengan kualitas yang baik (Suryawati, 2006). Ada beberapa aktivitas dalam menciptakan kualitas yang baik, salah satu yang terpenting adalah pengendalian kualitas. Pengendalian kualitas penting dilakukan agar produk yang dihasilkan oleh perusahaan sesuai dengan standar yang telah ditetapkan perusahan dan standar yang telah ditetapkan oleh badan yang berwenang (Suryawati, 2006).

Fenomena globalisasi juga berdampak terhadap rumah sakit, dimana rumah sakit pada era globalisasi ini bukan hanya mengemban misi sosial. Aspek bisnis dalam pengelolaan suatu rumah sakit sudah menjadi suatu konsekuensi wajar pada era globalisasi. Karena itu rumah sakit tidak

1. Alumni Program Magister Manajemen Pascasarjana Universitas Mataram

2. Dosen Pembimbing Utama, Dosen Program Magister Manajemen Pascasarjana Universitas Mataram

3. Dosen Pembimbing Pendamping, Dosen Program Magister Manajemen Pascasarjana Universitas Mataram 


\section{JMM JURNAL M MASISTER MANAEEEEN UNIVERSITAS MATARAM UNRAM

perlu lagi mengesampingkan upaya untuk lebih mempromosikan diri. Prasarana dan fasilitas rumah sakit serta kemajuan ilmu kedokteran perlu dijelaskan kepada masyarakat, mengingat persaingan pelayanan medis semakin ketat (Suryawati, 2006).

Penilaian mutu rumah sakit dapat diukur dari berbagai aspek, baik yang berpengaruh secara langsung maupun tidak langsung terhadap pelayanan yang diberikan. Beberapa aspek yang berpengaruh terhadap mutu pelayanan kesehatan di rumah sakit antara lain aspek klinis medis, efektifitas dan efisiensi pelayanan yang diberikan, keselamatan pasien dan kepuasan pasien (Sudewi \& Suryawati, 2006).

Dalam pengalaman sehari-hari, ketidakpuasan pasien yang paling sering dikemukakan dalam kaitannya dengan sikap dan perilaku petugas rumah sakit antara lain keterlambatan pelayanan dokter dan perawat, dokter sulit ditemui, dokter yang kurang komunikatif dan informatif, lamanya proses masuk rawat, aspek pelayanan seperti hotel di rumah sakit, serta ketertiban dan kebersihan lingkungan rumah sakit. Faktor sikap, perilaku, tutur kata, keacuhan, keramahan petugas, serta kemudahan mendapatkan informasi dan komunikasi menduduki peringkat yang tinggi dalam persepsi kepuasan pasien di rumah sakit. Tidak jarang walaupun pasien atau keluarganya merasa realisasi pelayanan tidak sesuai dengan harapannya merasa cukup puas karena dilayani dengan sikap yang menghargai perasaan dan martabatnya (Suryawati, 2006).

Menurut Kotler (1997), kepuasan merupakan tingkat perasaan seseorang (pelanggan) setelah membandingkan antara kinerja atau hasil yang dirasakan (pelayanan yang diterima dan dirasakan) dengan yang diharapkan. Kepuasan pasien merupakan nilai subjektif terhadap kualitas pelayanan yang diberikan dan diterima oleh pasien. Meskipun nilai subjektif ini sangat dipengaruhi oleh tingkat pendidikan, latar belakang sosial ekonomi, budaya, lingkungan, pekerjaan, kepribadian dan pengalaman masa lalu pasien, kepuasan pasien tetap akan didasari oleh kebenaran dan kenyataan objektif yang dialami oleh pasien pada saat menerima pelayanan di rumah sakit (Sudewi \& Suryawati, 2006).

Rumah sakit sebagai salah satu institusi pelayanan publik memegang peranan penting bagi peningkatan derajat kesehatan masyarakat. Rumah sakit dituntut untuk dapat melayani masyarakat, dapat berkembang dan mandiri serta harus mampu bersaing dan memberikan pelayanan yang bermutu dan terjangkau bagi masyarakat. Dengan semakin tingginya tuntutan bagi rumah sakit untuk meningkatkan pelayanannya, banyak permasalahan yang muncul terkait dengan terbatasnya anggaran yang tersedia bagi operasional rumah sakit, alur birokrasi yang terlalu panjang dalam proses pencairan dana, aturan pengelolaan keuangan yang menghambat kelancaran pelayanan dan sulitnya untuk mengukur kinerja, sementara rumah sakit memerlukan dukungan SDM, teknologi, dan modal yang sangat besar. Melalui konsep pola pengelolaan keuangan BLU ini rumah sakit diharapkan dapat meningkatkan profesionalisme, mendorong enterpreneureship, transparansi, dan akuntabilitas dalam rangka pelayanan publik, sesuai dengan tiga pilar yang diharapkan dari pelaksanaan PPK-BLU ini, yaitu mempromosikan peningkatan kinerja pelayanan publik, fleksibilitas pengelolaan keuangan dan tata kelola yang baik (Sri Mulyani, 2007).

Rumah Sakit Jiwa Provinsi Nusa Tenggara Barat (RSJ Provinsi NTB), sebagai salah satu sub sistem penyelenggaraan peningkatan kesehatan memiliki peran dalam penyelenggaraan pelayanan kesehatan melalui tenaga dokter yang profesional, peralatan medis, pelayanan laboratorium, farmasi, pelayanan perawatan, penelitian dan pendidikan tenaga dokter dan paramedis. Karena sangat pentingnya peranan rumah sakit ini dalam sistem kesehatan masyarakat, khususnya dalam 


\section{$J M M$ UNRAM

menangulangi gangguan mental yang cenderung meningkat, maka diperlukan pendekatan terpadu untuk melakukan kegiatan secara ekonomis, efisien, efektif. Sebagai lembaga yang padat modal, padat karya, dan padat ilmu serta teknologi, rumah sakit ini memerlukan profesionalisme yang handal dalam pengelolaan bisnis modern. Melalui Pola Pengelolaan Keuangan Badan Layanan Umum,(PPK-BLU), RSJP NTB diharapkan mampu meningkatkan kinerja pelayanannya kepada masyarakat dalam rangka memajukan kesejahteraan umum dan mencerdaskaan kehidupan bangsa, dengan memberikan fleksibilitas dalam pengelolaan keuangan berdasarkan prinsip ekonomi dan produktivitas, dan penerapan praktek bisnis yang sehat.

Rumah Sakit Jiwa Provinsi Nusa Tenggara Barat (RSJ Provinsi NTB), sebagai Lembaga Teknis Daerah (LTD) satu-satunya di Provinsi NTB yang khusus menangani pelayanan rujukan dan pengembangan pelayanan dibidang kesehatan jiwa mempunyai kewajiban mendukung terwujudnya visi dan misi pemerintah daerah dengan melaksanakan tugas pokok dan fungsinya sebaik-baiknya termasuk mensukseskan pelaksanaan Jaminan Kesehatan Nasional (JKN).

Terbitnya Undang-Undang No.1 tahun 2004 tentang perbendaharaan Negara, UndangUndang No.44 tahun 2009 tentang rumah sakit dan Peraturan Pemerintah No.23 tahun 2005 tentang Pola Pengelolaan Keuangan Badan Layanan Umum (PPK-BLU) serta Peraturan Menteri Dalam Negeri No.61 tahun 2007 tentang Pola Pengelolaan Keuangan Badan Layanan Umum Daerah (PPKBLUD) mengamanatkan semua rumah sakit menerapkan PPK-BLU/BLUD. Untuk memenuhi amanat tersebut, RSJ Provinsi mengusulkan menjadi PPK-BLU/BLUD dan dilaunching pada tahun 2010 dan diperkuat dengan Surat Keputusan Gubernur NTB No.56 tahun 2011 tanggal 25 Januari 2011. Akan tetapi penerapannya dimulai tahun 2012 karena kendala payung hukum yang belum terselesaikan dan tahun 2013 merupakan tahun kedua penerapan PPK-BLUD di RSJ Provinsi NTB.

\subsection{Perumusan masalah}

Berdasarkan uraian yang telah dikemukakan pada latar belakang dan judul penelitian, maka dapat disusun rumusan masalah:

1. Bagaimanakah kepuasan keluarga pasien sebelum dan sesudah PPK-BLUD?

2. Apakah terdapat perbedaan yang signifikan antara kepuasan keluarga pasien sebelum dan sesudah PPK-BLUD?

\subsection{Tujuan Penelitian}

Tujuan dilakukannya penelitian ini adalah:

1. Untuk menganalisis pengaruh perubahan status pengelolaan terhadap kepuasan pelayanan di Poli Psikiatri RSJ Provinsi NTB.

2. Untuk membandingkan dan menganalisis kepuasan sebelum dan sesudah penerapan status pengelolaan menjadi PPK-BLU di Poli Psikiatri RSJ Provinsi NTB.

\section{TINJAUAN PUSTAKA}

\subsection{Penelitian Terdahulu}

Penelitian Agustina (2003), tentang hubungan keterjangkauan pelayanan dengan kepuasan keluarga pasien skizofrenia yang berobat jalan di rumah sakit Sa'anim Padang. Hasil penelitian menunjukkan bahwa proporsi keluarga pasien yang puas sebesar $61,5 \%$ dan yang tidak puas 


\section{$J M M$ UNRAM

sebesar 38,5\%. Analisis lanjut menunjukkan bahwa tidak ada hubungan keterjangkauan pelayanan keluarga dengan kepuasan keluarga.

Berdasarkan hasil penelitian diatas, maka benang merah yang dapat diambil adalah bawa mutu pelayanan di rumah sakit berbanding lurus dengan kepuasan pasien. Penelitianpenelitian terdahulu tentang kepuasan pasien rawat inap dilakukan di RSU, sedangkan penelitian yang dilakukan di RSJ tidak mengkaikannya dengan pelayanan rawat jalan. Penelitian ini akan menganalisis lebih jauh tingkat kepuasan pasien rawat jalan dengan membandingkan antara kualitas pelayanan setelah PPK-BLU dengan sebelum PPK_BLUD.

Penelitian Sahnijar (2014), tentang faktor-faktor yang berhubungan dengan kepuasan kerja perawat pelaksana dalam pemberian asuhan keperawatan di Ruang Rawat Inap Badan Layanan Umum Daerah Rumah Sakit Jiwa Aceh Unit Filial Rumah Sakit Umum Daerah Jantho, hasil penelitian menunjukkan tidak ada hubungan faktor pekerjaan dengan kepuasan kerja perawat pelaksana dalam penerapan asuhan keperawatan, sub variabel lain terdapat hubungan faktor imbalan dengan kepuasan kerja, faktor kondisi kerja dengan kepuasan kerja dan tidak ada hubungan faktor rekan kerja dengan kepuasan kerja.

Penelitian Angka (2009) tentang hubungan kualitas pelayanan dengan tingkat kepuasan pengguna jasa transportasi transjakarta (studi kasus pada transjakarta jalur Pulo GadungKalideres DKI Jakarta), didapatkan hasil penelitian menunjukkan bahwa terjadi hubungan yang positif dan signifikan antara kualitas pelayanan dengan tingkat kepuasan pengguna jasa transportasi Transjakarta. Artinya semakin besar kualitas pelayanan yang diberikan maka akan berdampak pada kepuasan pelanggan yang semakin tinggi pula. Upaya BLUD Transjakarta mengenai kualitas pelayanan yang ada belum cukup baik bagi kepuasan pengguna jasa transportasi Transjakarta. Untuk itu BLUD perlu melakukan beberapa pembenahan seperti penambahan jumlah armada, menjaga kebersihan halte, menetapkan disiplin petugas dengan memberikan sanksi terhadap petugas yang tidak menepati waktu kedatangan armada.

Penelitian Wira (2014), tentang hubungan antara persepsi mutu pelayanan asuhan keperawatan dengan kepuasan pasien rawat inap kelas III di RSUD Wangaya Kota Denpasar, mendapatkan bahwa kehandalan, daya tanggap, jaminan, empati, mempunyai hubungan yang bermakna dengan kepuasan pasien rawat inap kelas III di RSUD Wangaya.

\subsection{Konsep Kepuasan}

\subsubsection{Pengertian Kepuasan Pasien}

Kepuasan menurut Kamus Bahasa Indonesia adalah puas; merasa senang; perihal (hal yang bersifat puas, kesenangan, kelegaan dan sebagainya). Kepuasan dapat diartikan sebagai perasaan puas, rasa senang dan kelegaan seseorang dikarenakan mengkonsumsi suatu produk atau jasa untuk mendapatkan pelayanan suatu jasa.

Menurut Oliver (dalam Supranto, 2001) mendefinisikan kepuasan sebagai tingkat perasaan seseorang setelah membandingkan kinerja atau hasil yang dirasakannya dengan harapannya. Tingkat kepuasan merupakan fungsi dari perbedaan antara kinerja yang dirasakan dengan harapan. Apabila kinerja dibawah harapan, maka pasien akan sangat kecewa. Bila kinerja sesuai harapan, maka pasien akan sangat puas. Sedangkan bila kinerja melebihi harapan pasien akan sangat puas harapan pasien dapat dibentuk oleh pengalaman masa lampau, komentar dari kerabatnya serta janji 


\section{JMM JURNAL M MASISTER MANAEEEEN UNIVERSITAS MATARAM UNRAM

dan informasi dari berbagai media. Pasien yang puas akan setia lebih lama, kurang sensitive terhadap harga dan memberi komentar yang baik tentang perusahaan tersebut.

Menurut Kotler (1988) kepuasan adalah tingkat kepuasan seseorang setelah membandingkan kinerja atau hasil yang dirasakan dibandingkan dengan harapannya. Jadi kepuasan atau ketidakpuasan adalah kesimpulan dari interaksi antara harapan dan pengalaman sesudah memakai jasa atau pelayanan yang diberikan. Upaya untuk mewujudkan kepuasan pasien total bukanlah hal yang mudah, Mudie dan Cottom menyatakan bahwa kepuasan pasien total tidak mungkin tercapai, sekalipun hanya untuk sementara waktu (Tjiptono, 1997).

Berdasarkan uraian dari beberapa ahli tersebut diatas, maka dapat disimpulkan bahwa kepuasan adalah perasaan senang, puas individu karena antara harapan dan kenyataan dalam memakai dan pelayanan yang diberikan terpenuhi.

Memahami kebutuhan dan keinginan konsumen dalam hal ini pasien adalah hal penting yang mempengaruhi kepuasan pasien. Pasien yang puas merupakan aset yang sangat berharga karena apabila pasien puas mereka akan terus melakukan pemakaian terhadap jasa pilihannya, tetapi jika pasien merasa tidak puas mereka akan memberitahukan dua kali lebih hebat kepada orang lain tentang pengalaman buruknya. Untuk menciptakan kepuasan pasien suatu perusahaan atau rumah sakit harus menciptakan dan mengelola suatu system untuk memperoleh pasien yang lebih banyak dan kemampuan untuk mempertahankan pasiennya.

Namun upaya untuk perbaikan atau kesempurnaan kepuasan dapat dilakukan dengan berbagai strategi oleh perusahaan untuk dapat merebut pasien. Junaidi (2002) berpendapat bahwa kepuasan konsumen atas suatu produk dengan kinerja yang dirasakan konsumen atas poduk tersebut. Jika kinerja produk lebih tinggi dari harapan konsumen maka konsumen akan mengalami kepuasan.

Hal yang hampir serupa dikemukakan oleh Indarjati (2001) yang menyebutkan adanya tiga macam kondisi kepuasan yang bisa dirasakan oleh konsumen berkaitan dengan perbandingan antara harapan dan kenyataan, yaitu jika harapan atau kebutuhan sama dengan layanan yang diberikan maka konsumen akan merasa puas. Jika layanan yang diberikan pada konsumen kurang atau tidak sesuai dengan kebutuhan atau harapan konsumen maka konsumen menjadi tidak puas. Kepuasan konsumen merupakan perbandingan antara harapan yang dimiliki oleh konsumen dengan kenyataan yang diterima oleh konsumen dengan kenyataan yang diterima oleh konsumen dengan kenyataan yang diterima oleh konsumen pada saat mengkonsumsi produk atau jasa.

\subsubsection{Indikator Kepuasan Pasien}

Dalam konsep quality assurance $(Q A)$, kepuasan pelanggan dipandang sebagai unsur penentu penilaian baik buruknya sebuah rumah sakit. Unsur penentu lainnya dari empat komponen yang mempengaruhi kepuasan adalah: aspek klinis, efisiensi dan efektivitas dan keselamatan pelanggan. Aspek Klinis, merupakan komponen yang menyangkut pelayanan dokter, perawat dan terkait dengan teknis medis. Efisiensi dan efektivitas, menunjuk pada pelayanan yang murah, tepat guna, tidak ada diagnosa dan terapi yang berlebihan. Aspek Keselamatan pelanggan, adalah upaya perlindungan pelanggan dari hal-hal yang dapat membahayakan keselamatan pelanggan, seperti jatuh, kebakaran, dll. Kepuasan pelanggan, sangat berhubungan dengan kenyaman, keramahan, dan kecepatan pelayanan.

Jaminan mutu pelayanan di Rumah Sakit (RS) merupakan salah satu faktor penting dan fundamental khsususnya bagi manajemen RS itu sendiri dan para stakeholdernya, pasalnya dampak dari QA menentukan hidup matinya sebuah rumah sakit. Bagi Rumah Sakit, adanya QA yang baik tentu saja membuat RS mampu untuk bersaing dan tetap exist di masyarakat. Bagi pelanggan, QA dapat dijadikan sebagai faktor untuk memilih RS yang bermutu dan baik. Bagi 


\section{$J M M$ UNRAM

praktisi medis, selain terikat dengan standar profesinya, dengan adanya QA para praktisi medis dituntut untuk semakin teliti, telaten, dan hati2 dalam menjaga mutu pelayanannya. Dan bagi pemerintah sendiri, adanya QA dapat menjadikan standar dalam memutuskan salah benarnya suatu kasus yang terjadi di Rumah sakit (Heriandi, 2007).

Parasuraman (1990) menyatakan dimensi kepuasan difokuskan menjadi 5 dimensi (ukuran) kualitas jasa atau pelayanan, yaitu:

1) Responsiveness (cepat tanggap); yaitu kemauan untuk membantu pelanggan (konsumen) dan menyediakan jasa/ pelayanan yang cepat dan tepat.

2) Assurance (kepastian); mencakup pengetahuan dan keramah-tamahan para karyawan dan kemampuan mereka untuk menimbulkan kepercayaan dan keyakinan, kesopanan dan sifat dapat dipercaya yang dimiliki para staf, bebas dari bahaya, risiko atau keragu-raguan.

3) Tangible (berwujud); meliputi penampilan fisik dari fasilitas, peralatan,karyawan dan alat-alat komunikasi.

4) Emphaty (empati); meliputi pemahaman pemberian perhatian secara individual kepada pelanggan, kemudahan dalam melakukan komunikasi yang baik, dan memahami kebutuhan pelanggan.

5) Reliability (keandalan); yakni kemampuan untuk melaksanakan jasa yang telah dijanjikan secara konsisten dan dapat diandalkan (akurat).

\subsubsection{Faktor-Faktor Yang Mempengaruhi Kepuasan Pasien}

Menurut pendapat Budiastuti (2002) mengemukakan bahwa pasien dalam mengevaluasi kepuasan terhadap jasa pelayanan yang diterima mengacu pada beberapa faktor, antara lain :

1. Kualitas produk atau jasa

Pasien akan merasa puas bila hasil evaluasi mereka menunjukkan bahwa produk atau jasa yang digunakan berkualitas. Persepsi konsumen terhadap kualitas poduk atau jasa dipengaruhi oleh dua hal yaitu kenyataan kualitas poduk atau jasa yang sesungguhnya dan komunikasi perusahaan terutama iklan dalam mempromosikan rumah sakitnya.

2. Kualitas Pelayanan

Kualitas pelayanan memegang peranan penting dalam industri jasa. Pelanggan dalam hal ini pasien akan merasa puas jika mereka memperoleh pelayanan yang baik atau sesuai dengan yang diharapkan.

3. Faktor emosional

Pasien yang merasa bangga dan yakin bahwa orang lain kagum terhadap konsumen bila dalam hal ini pasien memilih rumah sakit yang sudah mempunyai pandangan "rumah sakit mahal", cenderung memiliki tingkat kepuasan yang lebih tinggi.

4. Harga

Harga merupakan aspek penting, namun yang terpenting dalam penentuan kualitas guna mencapai kepuasan pasien. Meskipun demikian elemen ini mempengaruhi pasien dari segi biaya yang dikeluarkan, biasanya semakin mahal harga perawatan maka pasien mempunyai harapan yang lebih besar. Sedangkan rumah sakit yang berkualitas sama tetapi berharga murah, memberi nilai yang lebih tinggi pada pasien.

5. Biaya

Mendapatkan produk atau jasa, pasien yang tidak perlu mengeluarkan biaya tambahan atau tidak perlu membuang waktu untuk mendapatkan jasa pelayanan, cenderung puas terhadap jasa pelayanan tersebut. 


\section{TMM JURNAL MAGISTER MANAJEMEN UNIVERSITAS MATARAM

\subsection{Metode dan Teknik Pengukuran Kepuasan Pelanggan}

Tjiptono (2006:148) mengemukakan ada empat metode yang dapat digunakan setiap perusahaan untuk mengukur dan memantau kepuasan pelanggan (juga pelanggan perusahaan pesaing). Empat teknik untuk mengukur kepuasan pelanggan yaitu:

1. Sistem keluhan dan saran

Setiap perusahaan yang berorientasi pada pelanggan (customer oriented) perlu memberikan kesempatan seluas-luasnya bagi para pelanggannya untuk menyampaikan saran, pendapat, dan keluhan mereka. Media yang dapat digunakan meliputi kotak saran yang diletakkan ditempat strategis, menyediakan kartu komentar (guest comment), menyediakan saluran telephone khusus dan lain-lain. Informasi yang diperoleh melalui ini dapat memberikan ide-ide baru dan masukan yang berharga kepada perusahaan. Sehingga memungkinkan untuk memberikan respon secara tepat dan yang tanggap setiap masalah yang timbul.

2. Survey kepuasan pelanggan

Umumnya banyak penelitian mengenai kepuasan konsumen dilakukan dengan menggunakan metode survey, baik melalui pos, telephone maupun wawancara balik secara langsung dari konsumen. Pengukuran kepuasan pelanggan melalui metode ini dapat dilakukan berbagai cara diantaranya:

a. Directly Reported Satisfaction

Pengukuran dilakukan secara langsung melalui pertanyaan seperti ungkapan "seberapa puas saudara terhadap pelayanan perusahaan A pada skala berikut: sangat tidak puas, netral, puas, sangat puas.

b. Derived Dissatisfaction

Pertanyaan yang diajukan yakni besarnya harapan pelanggan terhadap atribut tertentu dan besarnya kinerja yang mereka rasakan.

c. Problem Analysis

Konsumen yang dijadikan responden diminta untuk mengungkapkan dua hal pokok, pertama, masalah yang mereka hadapi berkaitan dengan penawaran dari perusahaan, kedua, saran-saran untuk melakukan analysis.

d. Importance - performance analysis

Dalam teknik ini responden diminta untuk merangking berbagai elemen (atribut) dari penawaran berdasarkan derajat pentingnya setiap elemen. Selain itu responden juga diminta untuk merangking seberapa baik kinerja perusahaan dalam masing-masing elemen tersebut.

3. Ghost shopping

Metode ini dilaksanakan dengan mempekerjakan beberapa orang (ghost shopper) untuk berperan dan bersikap seperti pelanggan atau pembeli yang potensial dari produk perusahaan dan pesaing. Lalu mereka menyampaikan temuan-temuannya mengenai kekuatan dan kelemahan produk perusahaan dan perusahaan pesaing, berdasarkan pengalaman mereka juga mengamati dan menilai cara perusahaan pesaingnya menjawab pertanyaan pelanggan dan menangani setiap keluhan.

4. Lost customer analysis

Metode ini cukup unik. Perusahaan berusaha menghubungi para pelanggannya yang telah berhenti membeli atau beralih pemasok. Yang diharapkan adalah akan diperolehnya informasi 


\section{TMM JURNAL MAGISTER MANAJEMEN UNRAM

penyebab terjadinya hal tersebut. Informasi ini sangat bermanfaat bagi perusahaan untuk mengambil kebijakan selanjutnya dalam rangka meningkatkan kepuasan dan loyalitas pelanggan. Rangkuti (2006:87) menyatakan, teknik pengukuran kepuasan pelanggan dapat diukur dengan cara sebagai berikut:

a. Traditional approach

Berdasarkan pendekatan ini, konsumen memberikan penilaian atas masing-masing indikator produk atau jasa yang mereka nikmati (pada umumnya menggunakan skala likert) yaitu dengan cara memberikan rating dari 1 (sangat puas) sampai 5 (sangat tidak puas sekali). Nilai yang diperoleh dari skala likert ini dapat dipertimbangkan dengan dua cara yaitu dengan dibandingkan dengan nilai rata-rata atau dibandingkan dengan nilai secara keseluruhan, penelitian dengan keseluruhan merupakan nilai standar yang akan dibandingkan dengan nilai masing-masing indikator. Hasilnya adalah apabila nilai msingmasing indikator tersebut lebih tinggi dibandingkan nilai standar, konsumen dianggap sudah merasa puas, sebaliknya apabila masing-masing indikator tersebut lebih rendah dibandingkan nilai standar, konsumen dianggap tidak puas.

\section{Kerangka Konseptual Penelitian}

Berdasarkan latar belakang masalah, penelitian terdahulu dan kajian pustaka, maka dapat dirumuskan kerangka konseptual penelitian sebagai berikut :

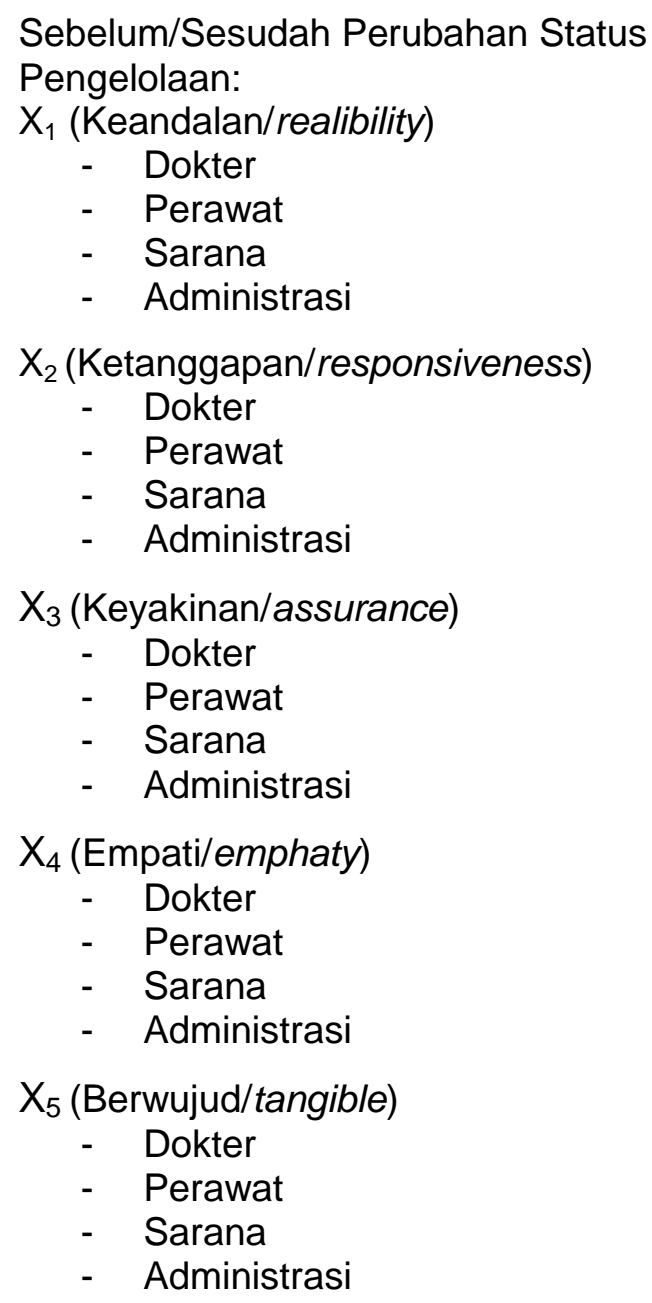




\section{$J M M$ UNRAM \\ JURNAL MAGISTER MANAJEMEN UNIVERSITAS MATARAM

Berdasarkan latar belakang masalah, penelitian terdahulu, kajian pustaka, landasan teori dan kerangka konspetual, maka dapat dirumuskan hipotesis penelitian ini sebagai berikut:

1. Diduga tingkat kepuasan keluarga pasien sebelum PPK-BLUD dalam kategori cukup puas dan sesudah PPK-BLUD dalam kategori puas.

2. Diduga tingkat kepuasan keluarga pasien sebelum dan sesudah PPK-BLUD berbeda secara siginifikan.

\section{METODE PENELITIAN}

Sesuai dengan perumusan masalah dan tujuan yang hendak dicapai, maka penelitian ini dapat digolongkan sebagai penelitian komparatif dengan pendekatan cros-sectional. Analisis komparatif bertujuan mengetahui perbandingan antara satu variabel dengan variabel lainnya (Suliyanto, 2006). Jadi penelitian ini akan menilai pengaruh perubahan status pengelolaan terhadap unsur-unsur kepuasan, yaitu responsiveness, assurance, tangible, emphat dan responsibility, sekaligus melakukan komparasi kepuasan sebelum dan sesudah PPK-BLUD.

\section{Lokasi penelitian}

Lokasi penelitian ini adalah pada instalasi ruang Poli Psikiatri RSJ Provinsi NTB. Lokasi ini dipilih karena RSJ Provinsi NTB merupakan satu-satunya rumah sakit jiwa di NTB.

\section{Metode Penelitian}

Mengingat populasi yang cukup besar, maka metode penelitian yang digunakan adalah sampel survey.

\section{Teknik Analisis Data Dan Uji Hipotesis}

Analisis data dan uji hipotesis dilakukan dalam dua tahap, pertama mengukur indeks kepuasan pelanggan/pasien kemudian kedua melakukan uji hipotesis beda dua mean untuk observasi tidak berpasangan.

\section{Mengukur Indeks Kepuasa Pasien}

Analisis hasil survei kepuasan pelanggan dapat dilakukan dengan memanfaatkan spreadsheet di Microsoft Excell dari elemen-elemen kunci pengukuran kepuasan pelanggan (Tjiptono, 2008b). Elemen-elemen kunci tersebut adalah dimensi importance (what matter most) dan dimensi kepuasan (what we do best) dari setiap variabel kunci. Dengan menggunakan skala numerik 10-poin, langkah-langkah analisis untuk menentukan Indeks Kepuasan Pasien adalah sebagai berikut: (Tjiptono 2008b)

1) Menentukan Skor Kepentingan (Importance)

Skor dimensi Kepentingan (importance) pada masing-masing faktor pada setiap variabel dijumlah, kemudian dihitung nilai rata-ratanya, dengan cara menjumlah hasil skor dibagi jumlah responden (Tijptono, 2008b:187).

\begin{tabular}{ll}
\hline & $\mathbf{I}_{\mathrm{f}}=\left(\mathbf{I}_{\mathbf{1}}+\mathbf{I}_{2}+\mathbf{I}_{3}+\mathbf{I}_{4}+\mathbf{I}_{5}+\ldots . . \mathbf{I}_{\mathbf{n}}\right) / \mathbf{n}$ \\
\hline $\mathrm{I}_{\mathrm{f}} \quad \begin{array}{c}\text { Skor rata-rata Improtance (kepentingan) masing- masing faktor/ } \\
\text { atribut }\end{array}$ \\
$\mathrm{I}_{1} \ldots \ldots \mathrm{I}_{\mathrm{n}}=$ & Skor Importance responden \\
$\mathrm{n} \quad=$ & Jumlah responden (Tjiptono, 2008b:187)
\end{tabular}




\section{TMM JURNAL MAgISTER MANAJEMEN UNIVERSITAS MATARAM

$\begin{array}{ll}\text { Skor rata-rata }>9 & =\text { faktor tersebut sangat penting } \\ \text { Skor rata-rata }>8-9 & =\text { faktor tersebut penting } \\ \text { Skor rata-rata }>7-8 & =\text { faktor tersebut agak penting } \\ \text { Skor rata-rata 6-7 } & \text { = faktor tersebut kurang penting } \\ \text { Skor rata-rata }<6 & =\text { faktor tersebut tidak penting. }\end{array}$

2) Menentukan Skor Kepuasan

Skor dimensi kepuasan pada masing-masing faktor pada setiap variabel dijumlah, kemudian dihitung nilai rata-ratanya, dengan cara menjumlah hasil skor dibagi jumlah responden.

\begin{tabular}{ll}
\hline$S_{f}=\left(S_{1}+S_{2}+S_{3}+S_{4}+S_{5}+\ldots . S_{n}\right) / n$ \\
$S_{\mathrm{f}} \quad=\begin{array}{l}\text { Skor rata-rata Satisfaction (Kepuasan) masing-masing faktor/ } \\
\text { atribut/unsur }\end{array}$ \\
$S_{1} \ldots . . . S_{\mathrm{n}}=$ & Skor Satisfaction responden \\
$\mathrm{n}$ & $=$ jumlah responden (Tjiptono, 2008b: 189)
\end{tabular}

Skor rata-rata $>9=$ palanggan sangat puas

Skor rata-rata $>8-9=$ pelanggan puas

Skor rata-rata $>7-8 \quad=$ pelanggan cukup puas

Skor rata-rata 6-7 = pelanggan kurang puas

Skor rata-rata $<6=$ pelanggan tidak puas

3) Menghitung faktor pembobot

Skor importance digunakan sebagai faktor pembobot. Untuk menghitung faktor pembobot, semua skor importance dijumlahkan, kemudian masing-masing skor importance dibagi dengan skor total tersebut dan dikalikan dengan 100persen.

4) Menghitung in

$$
\begin{gathered}
\mathrm{FP}=\left(\mathrm{I}_{\mathrm{f}} / \Sigma \mathrm{I}_{\mathrm{f}}\right) \times 100 \% \\
\mathrm{Fp}=\text { Faktor Pembobot } \\
\mathrm{I}_{\mathrm{f}}=\text { Skor Importance (Kepentingan ) }
\end{gathered}
$$

Langkah berik massing-masing unsur

Langkah berik (Tjiptono, 2008b: 191) skor kepuasan terumbang aengan cara mengauкаn masing-masing skor kepuasan dengan faktor pembobot. Semua skor kepuasan tertimbang dijumlahkan, kemudian dibagi 10 (skor teringgi karena menggunakan skala 10 poin), lalu hasilnya dikalikan $100 \%$. Hasil akhir yang ditemukan sama dengan Indeks Kepuasan Pelanggan

Indeks Kepuasan Pelanggan $=\Sigma\left(S_{\mathrm{f}} \times \mathrm{FP}\right) / 10 \times 100 \%$

$\mathrm{S}_{\mathrm{f}}=$ skor kepuasan masing-masing unsur penilaian variabel

$\mathrm{FP}=$ faktor pembobot

$10=$ skor kepuasan tertinggi (dari skala numerik10 poin)

(Tjiptono, 2008b: 192) 


\section{$J M M$ UNRAM

\subsubsection{Uji Hipotesis}

Selanjutnya hipotesis penelitian akan diuji dengan menggunakan uji hipotesis beda dua mean untuk observasi tidak berpasangan (Subagyo, 2005). Langkah-langkah dalam melaksanakan uji hipotesis beda dua mean untuk observasi tidak berpasangan, adalah:

1) Menyusun formulasi hipotesis nihil $\left(\mathrm{H}_{0}\right)$ dan hipotesis alternatif $\left(\mathrm{H}_{1}\right)$ :

$\mathrm{H}_{0}: \mu_{1}=\mu_{2}$ atau $\left(\mu_{1}-\mu_{2}\right)=0$

$\mathrm{H}_{1}: \mu_{1} \neq \mu_{2}$ atau $\left(\mu_{1}-\mu_{2}\right) \neq 0$

Untuk menguji formulasi diatas digunakan pengujian dua sisi.

2) Level significance $\alpha=0,05$.

3) Kriteria pengujian (rule of the test).

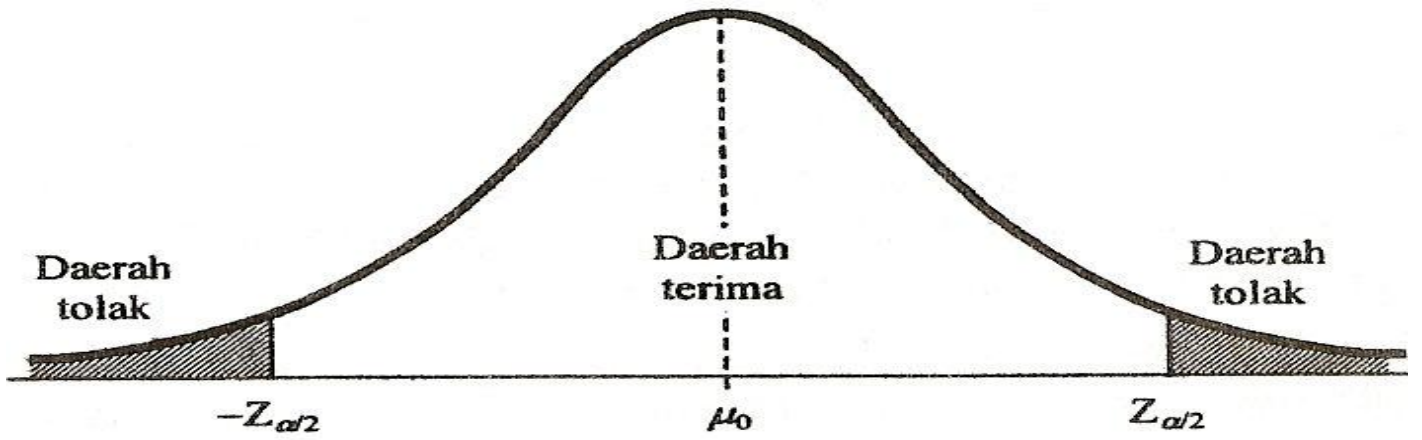

$\mathrm{H}_{0}$ gagal ditolak apabila: $-\mathrm{Z}_{\mathrm{\alpha} / 2} \leq \mathrm{Z} \leq \mathrm{Z}_{\mathrm{\alpha} / 2}$

$\mathrm{H}_{0}$ ditolak apabila: $\mathrm{Z}>\mathrm{Z}_{\mathrm{\alpha} / 2}$ atau $\mathrm{Z}<-\mathrm{Z}_{\mathrm{\alpha} / 2}$

4) Perhitungan nilai $Z$.

Dari sampel yang diambil kemudian dihitung nilai $\mathrm{Z}$ dengan rumus:

$$
\mathrm{Z}=\frac{\bar{X}_{1}-\bar{X}_{2}-\left(\mu_{1}-\mu_{2}\right)}{\sqrt{\frac{\sigma_{1}^{2}}{\mathrm{n}_{1}}+\frac{\sigma_{2}^{2}}{\mathrm{n}_{2}}}}
$$

\section{HASIL PENELITIAN}

Rumah Sakit Jiwa (RSJ) Provinsi Mataram didirikan berdasarkan surat Penunjukan Direktur Jenderal Pelayanan Kesehatan tanggal 31 Oktober 1983 No. 17867/Yankes/DKJ/1983 kepada PT. Yodya Karya, Jl. D.I Panjaitan No.8 Cawang Jakarta dan Perwakilannya di Provinsi Nusa Tenggara Barat sebagai Konsultan Perencanaan, dengan tugas pembuatan Masterplan Rumah Sakit Jiwa Mataram dan pembuatan design/dokumen tender dan memberikan penjelasan dalam "aanwijzing". Rumah Sakit Jiwa Mataram didirikan dengan pertimbangan bahwa Rumah Sakit Jiwa Selebung (milik Daerah) tidak dapat dikembangkan karena letaknya terpencil dan bangunannya tidak memenuhi syarat sebagai Rumah Sakit.

Pada bulan Agustus 2010 berdasarkan Peraturan Daerah No. 8 Tahun 2010 RSJ Pusat Mataram berubah status menjadi Lembaga Teknis Daerah (LTD) dengan nama RSJ Provinsi, yang merupakan rumah sakit khusus tipe B dengan tugas pokok dan fungsi memberikan pelayanan kesehatan rujukan dibidang kesehatan jiwa termasuk rehabilitasi korban penyalahgunaan Napza, konseling dan pengobatan HIV/AIDS bagi masyarakat NTB dan daerah lainnya.

Sampai dengan Desember 2010 Sumber Daya Manusia (SDM) yang tersedia di RSJ Provinsi berjumlah 212 orang (termasuk 2 orang PTT, dan 3 orang dokter spesialis paruh waktu), 


\section{JMM JURNAL M MASISTRE MANAEEEEN UNIVERSITAS MATARAM UNRAM

\author{
VOL. 5 No. 4 NOVEMBER 2016
}

merupakan tenaga fungsional, struktural dan non fungsional, terdiri dari tenaga dokter spesialis, dokter umum, psikolog, keperawatan, tenaga kesehatan lain dan tenaga administrasi. Jumlah tenaga tahun 2010 mengalami peningkatan dibandingkan tahun 2009 sebesar 30,86 persen (jumlah tenaga tahun 2009162 orang). Peningkatan kualitas dan kuantitas sumber daya manusia masih perlu dilakukan untuk memenuhi standar yang ditetapkan dan mendukung upaya RSJ Provinsi NTB memberikan pelayanan yang bermutu kepada masyarakat.

Sejak ditetapkan sebagai Badan Layanan Umum Daerah Pada tahun 2011, RSJ berupaya untuk meningkatkan mutu pelayanan dan melaksanakan Standar Pelayanan Minimal yang telah ditetapkan. Visi RSJ adalah menjadi Rumah Sakit Jiwa Dambaan Masyarakat dengan Mutu Layanan Terkini dan salah satu misinya meningkatkan pelayanan kesehatan jiwa yang bermutu standar nasional dalam rangka mewujudkan pelayanan yang profesional. Untuk mewujudkan itu, saat ini RSJ dituntut untuk memberikan pelayanan yang lebih baik dan mengembangkan jenis-jenis pelayanan sesuai kebutuhan masyarakat.

\section{Validitas Dan Reliabilitas Instrumen}

Untuk uji validitas dan reliabilitas instrumen dilakukan uji pendahuluan terhadap 30 responden tanpa memilah pasien jamkesmas atau non Jamkesmas dengan kriteria pengambilan sampel sama dengan sampel penelitian. Uji reliabilitas dan validitas responden dilakukan dengan analisis statistik menggunakan software Statistical Product and Service solution (SPSS) for Window Release 15.

Hasil uji validitas kuesioner variabel pelayanan dokter, pelayanan perawat, pelayanan penunjang dan pelayanan administrasi menunjukkan semua item memiliki r-hitung lebih besar dari r Tabel sehingga dinyatakan valid dengan $r$ Tabel 0,361 untuk 30 responden. Skor rata - rata variabel dimensi kepentingan $0,566-0,923$, sedangkan untuk variabel kepuasan 0,588 -0,887.

Hasil uji reliabilitas untuk semua variabel memiliki r-alpha hitung lebih besar dari r-Tabel 0,361 dimana koefisien alpha 0,966 untuk dimensi kepentingan sedangkan untuk kepuasan 0,969 sehinga kuesioner yang disusun untuk variabel tersebut sudah reliabel.

\section{Karakteristik Responden}

Karakteristik responden pada penelitian ini adalah berdasarkan jenis kelamin, umur, pekerjaan, tingkat pendidikan, lama hari rawat, besar penghasilan pasien/keluarga dan pembiayaan selama dirawat.

Berdasarkan jenis kelamin diperoleh hasil bahwa responden berjenis kelamin laki- laki lebih banyak dari pada perempuan. Responden laki-laki sebanyak 117 orang $(74,1 \%)$ dan perempuan sebanyak 41 orang $(25,9 \%)$.

Pada karakteristik umur pekerjaan yang paling banyak adalah tidak bekerja. Responden yang bekerja sebagai petani sebanyak 27 orang $(17,1 \%)$, wiraswasta sebanyak 46 orang $(29,1 \%)$, buruh sebanyak 11 orang $(7,0 \%)$, pegawai negri sebanyak 15 orang $(9,5 \%)$ dan guru sebanyak 5 orang $(3,2 \%)$.

Untuk kelompok pendidikan, persentasi tertinggi adalah lulus sekolah dasar. Responden yang tidak sekolah sebanyak 13 orang $(8,2 \%)$, lulusan SLTP sebanyak 48 orang $(30,4 \%)$, lulusan SLTA sebanyak 25 orang $(15,8 \%)$, lulusan diploma sebanyak 13 orang $(8,2 \%)$ dan lulusan sarjana sebanyak 9 orang $(5,7 \%)$.

Pada karakteristik penghasilan per bulan, persentasi responden terbanyak adalah berpenghasilan antara Rp.500.000-Rp.1.000.000 yaitu 41,8\%. Responden yang penghasilan $<500.000$ 


\section{TMM JURNAL MAGISTER MANAJEMEN UNIVERSITAS MATARAM UNRAM

sebanyak 18 orang $(11,4 \%)$, penghasilan 1-2 juta sebanyak 50 orang $(31,6 \%)$ dan penghasilan $2-3$ juta sebanyak 24 orang $(15,2 \%)$.

\section{Skor Kepuasan Sebelum BLUD}

Berikut ditampilkan rata-rata skor kepuasan pada masing-masing komponen sebelum BLUD:

Tabel Skor Kepuasan Sebelum BLUD

\begin{tabular}{|l|c|}
\hline \multicolumn{1}{|c|}{ Komponen } & Rata-rata skor \\
\hline Reliability & 6,69 \\
\hline Assurance & 6,84 \\
\hline Tangible & 6,30 \\
\hline Emphaty & 6,87 \\
\hline Responsiveness & 7,59 \\
\hline
\end{tabular}

Berdasarkan tabel diatas, dapat diketahui bahwa rata-rata skor kepuasan sebelum BLUD pada komponen reliability sebesar 6,69, rata-rata skor kepuasan pada komponen assurance sebesar 6,84, rata-rata skor kepuasan pada komponen tangible sebesar 6,30, rata-rata skor kepuasan pada komponen emphaty sebesar 6,87 dan rata-rata skor kepuasan pada komponen responsiveness sebesar 7,59.

\section{Skor Kepuasan Sesudah BLUD}

Berikut ditampilkan rata-rata skor kepuasan pada masing-masing komponen sesudah BLUD:

Tabel 4.6. Skor Kepuasan Sesudah BLUD

\begin{tabular}{|l|c|}
\hline \multicolumn{1}{|c|}{ Komponen } & Rata-rata skor \\
\hline Reliability & 9,11 \\
\hline Assurance & 8,91 \\
\hline Tangible & 8,80 \\
\hline Emphaty & 8,96 \\
\hline Responsiveness & 9,25 \\
\hline
\end{tabular}

Berdasarkan tabel diatas, dapat diketahui bahwa rata-rata skor kepuasan sesudah BLUD pada komponen reliability sebesar 9,11, rata-rata skor kepuasan pada komponen assurance sebesar 8,91, rata-rata skor kepuasan pada komponen tangible sebesar 8,80, ratarata skor kepuasan pada komponen emphaty sebesar 8,96 dan rata-rata skor kepuasan pada komponen responsiveness sebesar 9,25.

\section{Perbandingan Skor Kepuasan Sebelum dan Sesudah BLUD}

Untuk menguji hipotesis penelitian, dilakukan uji hipotesis dengan menggunakan Uji Hipotesis Beda Dua Mean Untuk Observasi Berpasangan (Subagyo, 2005). 


\section{$J M M$ UNRAM \\ JURNAL MAGISTER MANAJEMEN UNIVERSITAS MATARAM \\ VOL. 5 NO. 4 NOVEMBER 2016}

Perbandingan Skor Kepuasan Sebelum dan Sesudah BLUD

\begin{tabular}{|l|c|c|c|}
\hline \multicolumn{1}{|c|}{ Komponen } & $\begin{array}{c}\text { Rata-rata skor } \\
\text { kepuasan } \\
\text { sebelum BLUD }\end{array}$ & $\begin{array}{c}\text { Rata-rata skor } \\
\text { kepuasan } \\
\text { sesudah BLUD }\end{array}$ & p-value \\
\hline Reliability & 6,69 & 9,11 & 0,000 \\
\hline Assurance & 6,84 & 8,91 & 0,000 \\
\hline Tangible & 6,30 & 8,80 & 0,000 \\
\hline Emphaty & 6,87 & 8,96 & 0,000 \\
\hline Responsiveness & 7,59 & 9,25 & 0,000 \\
\hline
\end{tabular}

Berdasarkan tabel diatas, dapat diketahui bahwa rata-rata skor kepuasan sebelum BLUD pada komponen reliability sebesar 6,69 dan rata-rata skor kepuasan sesudah BLUD pada komponen reliability sebesar 9,11, dengan p-value 0,000 (lebih kecil dari alpha 0,05), sehingga dapat disimpulkan bahwa terdapat beda rata-rata skor kepuasan sebelum dan sesudah BLUD pada komponen reliability.

Rata-rata skor kepuasan sebelum BLUD pada komponen assurance sebesar 6,84 dan ratarata skor kepuasan sesudah BLUD pada komponen assurance sebesar 8,91, dengan p-value 0,000 (lebih kecil dari alpha 0,05), sehingga dapat disimpulkan bahwa terdapat beda rata-rata skor kepuasan sebelum dan sesudah BLUD pada komponen assurance.

Rata-rata skor kepuasan sebelum BLUD pada komponen tangible sebesar 6,30 dan rata-rata skor kepuasan sesudah BLUD pada komponen tangible sebesar 8,80, dengan p-value 0,000 (lebih kecil dari alpha 0,05), sehingga dapat disimpulkan bahwa terdapat beda rata-rata skor kepuasan sebelum dan sesudah BLUD pada komponen tangible.

Rata-rata skor kepuasan sebelum BLUD pada komponen emphaty sebesar 6,87 dan rata-rata skor kepuasan sesudah BLUD pada komponen emphaty sebesar 8,96, dengan p-value 0,000 (lebih kecil dari alpha 0,05), sehingga dapat disimpulkan bahwa terdapat beda rata-rata skor kepuasan sebelum dan sesudah BLUD pada komponen emphaty.

Rata-rata skor kepuasan sebelum BLUD pada komponen responsiveness sebesar 7,59 dan rata-rata skor kepuasan sesudah BLUD pada komponen responsiveness sebesar 9,25, dengan pvalue 0,000 (lebih kecil dari alpha 0,05), sehingga dapat disimpulkan bahwa terdapat beda rata-rata skor kepuasan sebelum dan sesudah BLUD pada komponen responsiveness.

\section{Pembahasan}

Menurut Oliver (dalam Supranto, 2001) mendefinisikan kepuasan sebagai tingkat perasaan seseorang setelah membandingkan kinerja atau hasil yang dirasakannya dengan harapannya. Menurut Kotler (1988) kepuasan adalah tingkat kepuasan seseorang setelah membandingkan kinerja atau hasil yang dirasakan dibandingkan dengan harapannya. Jadi kepuasan atau ketidakpuasan adalah kesimpulan dari interaksi antara harapan dan pengalaman sesudah memakai jasa atau pelayanan yang diberikan. Upaya untuk mewujudkan kepuasan pasien total bukanlah hal yang mudah, Mudie dan Cottom menyatakan bahwa kepuasan pasien total tidak mungkin tercapai, sekalipun hanya untuk sementara waktu (Tjiptono, 1997). 


\section{JMM JURNAL MAGISTER MANAJEMEN UNIVERSITAS MATARAM UNRAM

Memahami kebutuhan dan keinginan konsumen dalam hal ini pasien adalah hal penting yang mempengaruhi kepuasan pasien. Pasien yang puas merupakan aset yang sangat berharga karena apabila pasien puas mereka akan terus melakukan pemakaian terhadap jasa pilihannya, tetapi jika pasien merasa tidak puas mereka akan memberitahukan dua kali lebih hebat kepada orang lain tentang pengalaman buruknya. Untuk menciptakan kepuasan pasien suatu perusahaan atau rumah sakit harus menciptakan dan mengelola suatu system untuk memperoleh pasien yang lebih banyak dan kemampuan untuk mempertahankan pasiennya.

Namun upaya untuk perbaikan atau kesempurnaan kepuasan dapat dilakukan dengan berbagai strategi oleh perusahaan untuk dapat merebut pasien. Junaidi (2002) berpendapat bahwa kepuasan konsumen atas suatu produk dengan kinerja yang dirasakan konsumen atas poduk tersebut. Jika kinerja produk lebih tinggi dari harapan konsumen maka konsumen akan mengalami kepuasan.

Hal yang hampir serupa dikemukakan oleh Indarjati (2001) yang menyebutkan adanya tiga macam kondisi kepuasan yang bisa dirasakan oleh konsumen berkaitan dengan perbandingan antara harapan dan kenyataan, yaitu jika harapan atau kebutuhan sama dengan layanan yang diberikan maka konsumen akan merasa puas. Jika layanan yang diberikan pada konsumen kurang atau tidak sesuai dengan kebutuhan atau harapan konsumen maka konsumen menjadi tidak puas. Kepuasan konsumen merupakan perbandingan antara harapan yang dimiliki oleh konsumen dengan kenyataan yang diterima oleh konsumen dengan kenyataan yang diterima oleh konsumen dengan kenyataan yang diterima oleh konsumen pada saat mengkonsumsi produk atau jasa.

\section{Reliability}

Berdasarkan tabel diatas, dapat diketahui bahwa rata-rata skor kepuasan sebelum BLUD pada komponen reliability sebesar 6,69 dan rata-rata skor kepuasan sesudah BLUD pada komponen reliability sebesar 9,11, dengan p-value 0,000 (lebih kecil dari alpha 0,05), sehingga dapat disimpulkan bahwa terdapat beda rata-rata skor kepuasan sebelum dan sesudah BLUD pada komponen reliability.

Reliability yakni kemampuan untuk melaksanakan jasa yang telah dijanjikan secara konsisten dan dapat diandalkan (akurat) sebelum dan sesudah perubahan status pengelolaan. Indikatornya adalah kecepatan pelayanan, kemudahan administrasi, kecepatan tindakan, ketepatan pemeriksaan lab, serta kecepatan penerimaan hasil lab.

Bila kita lihat keadaan sebelum diterapkan PPK-BLUD standar pelayanan minimum (SPM) belum sepenuhnya dilakukan menyangkut pelayanan dokter, perawat dan petugas lainya belum seoptimal saat ini. Dalam konsep quality assurance (QA), kepuasan pelanggan dipandang sebagai unsur penentu penilaian baik buruknya sebuah rumah sakit. Unsur penentu lainnya dari empat komponen yang mempengaruhi kepuasan adalah: aspek klinis, efisiensi dan efektivitas dan keselamatan pelanggan. Aspek Klinis, merupakan komponen yang menyangkut pelayanan dokter, perawat dan terkait dengan teknis medis. Efisiensi dan efektivitas, menunjuk pada pelayanan yang murah, tepat guna, tidak ada diagnosa dan terapi yang berlebihan. Aspek Keselamatan pelanggan, adalah upaya perlindungan pelanggan dari hal-hal yang dapat membahayakan keselamatan pelanggan, seperti jatuh, kebakaran, dll. Kepuasan pelanggan, sangat berhubungan dengan kenyaman, keramahan, dan kecepatan pelayanan, namun hal ini perlu dibuktikan dengan penelitian yang lebih sempurna mengenai kualitas pelayanan di RSJ Provinsi NTB. 


\section{JMM JURNAL M MASISTER MANAEEEEN UNIVERSITAS MATARAM UNRAM

Assurance

Rata-rata skor kepuasan sebelum BLUD pada komponen assurance sebesar 6,84 dan ratarata skor kepuasan sesudah BLUD pada komponen assurance sebesar 8,91, dengan p-value 0,000 (lebih kecil dari alpha 0,05), sehingga dapat disimpulkan bahwa terdapat beda rata-rata skor kepuasan sebelum dan sesudah BLUD pada komponen assurance.

Assurance mencakup pengetahuan dan keramah-tamahan para karyawan dan kemampuan mereka untuk menimbulkan kepercayaan dan keyakinan, kesopanan dan sifat dapat dipercaya yang dimiliki para staf, bebas dari bahaya, risiko atau keragu-raguan sebelum dan sesudah perubahan status pengelolaan. Indikatornya adalah kemampuan mendiagnosis penyakit, keterampilan petugas kesehatan, pelayanan ramah, serta jaminan kepercayaan terhadap pelayanan. Pada saat belum diterapkan PPK-BLUD aspek tersebut sudah dilakukan namun kurang optimal dikarena quality anssurance belum menjadi standar utama dalam pelayanan.

Jaminan mutu pelayanan di Rumah Sakit (RS) merupakan salah satu faktor penting dan fundamental khsususnya bagi manajemen RS itu sendiri dan para stakeholdernya, pasalnya dampak dari QA menentukan hidup matinya sebuah rumah sakit. Bagi Rumah Sakit, adanya QA yang baik tentu saja membuat RS mampu untuk bersaing dan tetap exist di masyarakat. Bagi pelanggan, QA dapat dijadikan sebagai faktor untuk memilih RS yang bermutu dan baik. Bagi praktisi medis, selain terikat dengan standar profesinya, dengan adanya QA para praktisi medis dituntut untuk semakin teliti, telaten, dan hati2 dalam menjaga mutu pelayanannya. Dan bagi pemerintah sendiri, adanya QA dapat menjadikan standar dalam memutuskan salah benarnya suatu kasus yang terjadi di Rumah sakit (Heriandi, 2007).

\section{Tangible}

Rata-rata skor kepuasan sebelum BLUD pada komponen tangible sebesar 6,30 dan rata-rata skor kepuasan sesudah BLUD pada komponen tangible sebesar 8,80, dengan p-value 0,000 (lebih kecil dari alpha 0,05), sehingga dapat disimpulkan bahwa terdapat beda rata-rata skor kepuasan sebelum dan sesudah BLUD pada komponen tangible.

Tangible meliputi penampilan fisik dari fasilitas, peralatan,karyawan dan alat-alat komunikasi sebelum dan sesudah perubahan status pengelolaan. Penampilan fisik RSJ Provinsi NTB sebelum pelaksanaan PPK-BLUD masih tersetima seperti bangun lama yang yang tidak jauh dari kata angker dan serem saai ini setelah dimulai penerapan PPK-BLUD diumalainya pembangunan gedung yang representative modern dan sesuai dengan standar begitu pula dengan alat-alat medis yang ada sesuai dengan standar. Indikatornya adalah penataan ruangan yang baik, kebersihan/kerapihan ruangan, kerapihan penampilan petugas kesehatan, serta kesiapan/kelengkapan alat-alat.

\section{Emphaty}

Rata-rata skor kepuasan sebelum BLUD pada komponen emphaty sebesar 6,87 dan rata-rata skor kepuasan sesudah BLUD pada komponen emphaty sebesar 8,96, dengan p-value 0,000 (lebih kecil dari alpha 0,05), sehingga dapat disimpulkan bahwa terdapat beda rata-rata skor kepuasan sebelum dan sesudah BLUD pada komponen emphaty.

Emphaty meliputi pemahaman pemberian perhatian secara individual kepada pelanggan, kemudahan dalam melakukan komunikasi yang baik, dan memahami kebutuhan pelanggan sebelum dan sesudah perubahan status pengelolaan. Indikatornya adalah pemberian perhatian pasien, kepedulian terhadap pasien, keadilan pelayanan, serta pelayanan 24 jam. 


\section{JMM JURNAL M MACISTER MANAEEEEN UNIVERSITAS MATARAM UNRAM

\author{
VOL. 5 No. 4 NOVEMBER 2016
}

Tingkat kepuasan merupakan fungsi dari perbedaan antara kinerja yang dirasakan dengan harapan. Apabila kinerja dibawah harapan, maka pasien akan sangat kecewa. Bila kinerja sesuai harapan, maka pasien akan sangat puas. Sedangkan bila kinerja melebihi harapan pasien akan sangat puas harapan pasien dapat dibentuk oleh pengalaman masa lampau, komentar dari kerabatnya serta janji dan informasi dari berbagai media. Pasien yang puas akan setia lebih lama, kurang sensitive terhadap harga dan memberi komentar yang baik tentang perusahaan tersebut. Hal ini disebabkan keadaan kesejahteraan karyawan setelah penerapan PPK-BLUD mengalami perubahan yang lebih baik.

\section{Responsiveness}

Rata-rata skor kepuasan sebelum BLUD pada komponen responsiveness sebesar 7,59 dan rata-rata skor kepuasan sesudah BLUD pada komponen responsiveness sebesar 9,25, dengan pvalue 0,000 (lebih kecil dari alpha 0,05), sehingga dapat disimpulkan bahwa terdapat beda rata-rata skor kepuasan sebelum dan sesudah BLUD pada komponen responsiveness.

Responsiveness yaitu kemauan untuk membantu pelanggan (konsumen) dan menyediakan jasa/ pelayanan yang cepat dan tepat sebelum dan sesudah perubahan status pengelolaan. Indikatornya adalah kesiapsiagaan petugas dalam pelayanan, informasi yang jelas, prosedur yang mudah, reaksi petugas kesehatan, tidak menunggu pelayanan lebih dari satu jam.

Setiap perusahaan yang berorientasi pada pelanggan (customer oriented) perlu memberikan kesempatan seluas-luasnya bagi para pelanggannya untuk menyampaikan saran, pendapat, dan keluhan mereka. Media yang dapat digunakan meliputi kotak saran yang diletakkan ditempat strategis, menyediakan kartu komentar (guest comment), menyediakan saluran telephone khusus dan lain-lain. Informasi yang diperoleh melalui ini dapat memberikan ide-ide baru dan masukan yang berharga kepada perusahaan. Sehingga memungkinkan untuk memberikan respon secara tepat dan yang tanggap setiap masalah yang timbul.

\section{KESIMPULAN}

Berdasarkan hasil penelitian dan pembahasan dapat diambil kesimpulan sebagai berikut:

1. Dari variabel reliability rata-rata skor kepuasan sebesar 9,11 dengan p-value 0,000 (lebih kecil dari alpha 0,05 .

2. Rata-rata skor kepuasan pada komponen assurance sebesar 8,91, dengan p-value 0,000 (lebih kecil dari alpha 0,05),

3. Pada komponen tangible sebesar 8,80 , dengan p-value 0,000 (lebih kecil dari alpha 0,05 ), sehingga dapat disimpulkan bahwa terdapat beda rata-rata skor kepuasan sebelum dan sesudah BLUD.

4. Rata-rata skor kepuasan pada komponen emphaty sebesar 8,96, dengan p-value 0,000 (lebih kecil dari alpha 0,05

5. Rata-rata skor kepuasan sebelum BLUD pada komponen responsiveness sebesar 7,59 dan rata-rata skor kepuasan sesudah BLUD pada komponen responsiveness sebesar 9,25, dengan p-value 0,000 (lebih kecil dari alpha 0,05).

\section{DAFTAR PUSTAKA}

(2004), SK Menteri Pendayagunaan Aparatur Negara Republik Indonesia Nomor: KEP/25/M.PAN/2/2004 Tahun 2004 tentang Pedoman Umum Penyusunan Indeks 


\section{IMM JURNAL MAGISTER MANAJEMEN UNIVERSITAS MATARAM

Kepuasan Masyarakat Unit Pelayanan Instansi Pemerintah, Jakarta: Kementerian Pendayagunaan Aparatur Negara Republik Indonesia.

(2004), SK Menteri Pendayagunaan Aparatur Negara Nomor: KEP/26/M.PAN/2/2004 Tahun 2004 tentang Petunjuk Teknis Transparansi Dan Akuntabilitas Dalam Penyelenggaraan Pelayanan Publik, Jakarta: Kementerian Pendayagunaan Aparatur Negara Republik Indonesia.

(2009), Tingkat Kepuasan Masyarakat Terhadap Kualitas Pelayanan Di Instalasi Rawat Jalan Rumah Sakit Jiwa Provinsi NTB, Mataram: Rumah Sakit Jiwa Provinsi NTB

(2010), Tingkat Kepuasan Masyarakat Terhadap Kualitas Pelayanan Di Instalasi Rawat Jalan Rumah Sakit Jiwa Provinsi NTB, Mataram: Rumah Sakit Jiwa Provinsi NTB

(2010), Laporan Tahunan Rumah Sakit Jiwa Provinsi NTB, Mataram: Rumah Sakit Jiwa Provinsi NTB

Agustina, M (2003), “Hubungan keterjangkauan pelayanan dengan kepuasan keluarga pasien skizofrenia yang berobat jalan di Rumah Sakit Jiwa Prof.HB. Sa'anin Padang tahun 2003", tersedia di http://www.Eprint.lib.ui.id/10293/1/78003. (di akses 28 agustus 2011)

Aisyati, A dkk. (2007), “Analisa Kualita Pelayanan Rumah Sakit Umum Daerah (RSUD) Wonogiri menggunakan metode Fuzzy-Servqual", Gema Teknik, no. 2, Tahun X, 22-26, http://puslit2.petra.ac.id/ejournal/index.php/gem/article/viewFile/17601/17515 (di akses 1 November 2011)

Anurman Huda (2009), Analisis Tingkat Kepuasan Peserta Askes Sosial Terhadap Pelayanan Rawat Inap Di Kota Mataram (Studi Komparasi Pada Rumah Sakit Wirabhakti Dan Rumah Sakit Bhayangkara), Tesis, Mataram: Program Pasca Sarjana Unram.

Ariestonandri, Prima (2006), Marketing Research For Beginner (Panduan Praktis Riset Pemasaran Bagi Pemula), Yogyakarta: Penerbit ANDI.

Arikunto, Suharsimi. 1996, Prosedur penelitian, Jakarta, Rineka Cipta

Arikunto, Suharsimi. 2010, Prosedur penelitian,Suatu pendekatan Praktik, ed. Revisi, Jakarta, Rineka Cipta.

Azwar, A. (1996). Pengantar Administrasi Kesehatan, Jakarta: Binarupa Aksara

Cooper, Doald R dan Emory, C. William.(1999). Metode Penelitian Bisnis jilid 2, ed kelima. Penerbit Eralangga, jakarta,

Hermanto, D. (2010), Pengaruh Persepsi Mutu Pelayanan Kebidanan Terhadap Kepuasan Pasien Rawat Inap Kebidanan Di RSUD Dr. H. Soemarno Sosroatmodjo Bulungan Kalimantan Timur, Tesis. Semarang: Program Pasca Sarjana Universitas Dipenogoro.

Irawan, Handi (2002), 10 Prinsip Kepuasan Pelanggan, Jakarta: PT Gramedia. 


\section{$J M M$ UNRAM

Juni, S. (2001), Analisis Tingkat Kepuasan Pasien Intern dan Ekstern Terhadap Mutu Pelayanan Dalam Rangka Meningkatkan Admisi Rawat Inap PT Rumah Sakit Pelabuhan Surabaya, Tesis, Unair: Surabaya

Kaplan and Saddock, 1997. Sinopsi Psikiatri. Ilmu Pengetahuan dan Perilaku Psikiatri Klinis, Edisi ke tujuh, Jilid 1, Alih bahasa, Kusuma, Jakarta: Bina Rupa Aksara.

Kotler,P. (1997), Manajemen Pemasaran, Jakarta: PT Prenhallindo

Malhotra, Naresh K. (2005), Riset Pemasaran (Pendekatan Terapan), Edisi Keempat, Jilid 1 dan 2, Alih bahasa, Maryam, Jakarta: PT Indeks.

Manullang, I (2008), Pengaruh Kualitas Pelalyanan Terhadap Kepuasan Penggan Jasa Penerbangan PT. Garuda Indonesia Airlines di Bandara Polonia Medan.Tesis, Sekolah Pasca Sarjana, USU, eRepository

Pratiwi, AL (2010), Persepsi Pasien Jamkesmas Rawat Inap Terhadap Kualitas Pelayanan RSCM dengan Metode Servqual, Tesis, Magister Perencanaan dan Kebijakan Publik, jakarta: UI

Rachmadi (2008), Pengaruh Kualitas Pelayanan terhadap kepuasan pasien rawat inap kelas III di RSUD Kabupaten Karimun. Tesis Program Pasca Sarjana Magister Administrasi Publik, Jakarta: UT

Riduwan. 2009, Metode Dan Tenik Menyusun Tesis, Bandung, Alfabeta.

Setianto, IPA. (2010), Persepsi Pasien Jamkesmas Terhadap Kualitas Pelayanan BLUD Wangaya, Kota Denpasar, Tesis: Program Studi : Magister Perencanaan dan Kebijakan Publik, UI.

Subagyo, Pangestu, Djarwanto (2005), Statistika Induktif, Edisi 5, Yogyakarta: BPFE-Yogyakarta.

Sudewi, Ni Made Ratna A.S. (2006), "Kualitas Pelayanan Dan Kepuasan Pasien Di Rumah Sakit", makalah disampaikan pada Konferensi Nasional Praktik Pelayanan Kesehatan Di Indonesia Musyawarah Nasional Pamjaki III, Jakarta, 29-31 Agustus.

Suliyanto (2006), Metode Riset Bisnis, Yogyakarta: Penerbit ANDI.

Suryawati, Chriswardani, dkk (2006), "Penyusunan Indikator Kepuasan Pasien Rawat Inap Rumah Sakit Di Provinsi Jawa Tengah”, Jurnal Manajemen Pelayanan Kesehatan, Vol.09, No.4, Desember.

Tjiptono, F. (2008a), Strategi Pemasaran, Yogyakarta: Andi.

Tjiptono, F. (2008b), Service Management Mewujudkan Pelayana Prima, Yogyakarta: Andi.

Tjiptono, F dan Chandra, G. (2007), Service, Quality Satisfaction, edisi 2, Yogyakarta: andi

Utama, S. (2005), Memahami Fenomena Kepuasan Pasien Rumah Sakit, Jurnal Manajemen Pelayanan Kesehatan, 09 (1), 1-7.

Wijono. D. (2000), Manajemen Mutu Pelayanan Kesehatan Teori, Strategi dan Aplikasi, , Surabaya: Airlangga University Press. 


\section{TMM JURNAL MAGISTER MANAJEMEN UNIVERSITAS MATARAM UNRAM

Wiyono, dkk. Studi Kualitas Pelayanan Dan Kepuasan Konsumen Di Rumah Sakit Islam Manisrenggo Klaten, http://eprints.ums.ac.id/894/1/Jurnal_Daya_Saing_7_1_pdf, (download 5 Nov 2011).

Yumizone (2009). Skizofrenia. http:/ / yumizone.wordpress.com/2009/01/10/skizofrenia/ (down load 7 Feb 2012).

Zulfa, E (2009), Perbedaan Tingkat Kepuasan Pasien Peserta Jamkesmas Dan Pasien Umum Di Instalasi Rawat Jalan RSUD Cilegon-Banten 